\title{
RAMY PRAWNE WSPÓŁPRACY UNII EUROPEJSKIEJ Z ORGANIZACJĄ NARODÓW ZJEDNOCZONYCH W DZIEDZINIE OCHRONY PRAW CZLOWIEKA
}

Duża liczba funkcjonujących współcześnie rządowych organizacji międzynarodowych oraz szerokie spektrum stawianych przed nimi przez państwa zadań powoduja, że coraz częściej zakresy celów ustanowionych w statutach poszczególnych organizacji powielają się lub krzyżują. Ten fenomen dublowania się celów organizacji stał się przyczynkiem do rozwoju jednej z nowych sfer ich działalności, określanej mianem „interorganizacjonalizmu” (inter-organizationalism $)^{1}$ - tzn. współpracy organizacji międzynarodowych o zbliżonych obszarach zainteresowań. Chęć zapewnienia spójności i racjonalności działań rządowych organizacji międzynarodowych o zbliżonych celach statutowych stanowi niewątpliwe nowe wyzwanie zarówno dla praktyków, jak i dla badaczy problematyki organizacji międzynarodowych, poszukujących nowych: teoretycznych i instytucjonalnych, rozwiązań.

Jedna z bardziej eksponowanych sfer wspomnianej współpracy jest kooperacja w dziedzinie ochrony praw człowieka, która obejmuje zarówno poszukiwanie środków współdziałania na szczeblu organów organizacji, czego przykładem są próby koordynacji działalności ciał traktatowych ONZ, jak i na wyższym szczeblu - współpracy interorganizacjonalnej ${ }^{2}$. W tej drugiej sferze niewątpliwie godne uwagi jest współdziałanie Organizacji Narodów Zjednoczonych z Unią Europejska, które stanowi przedmiot istotnej debaty międzynarodowej, lecz wciąż nie zostało, jak się wydaje, wyczerpująco przedstawione w literaturze polskiej. Tym samym dokonanie analizy owej niezwykle złożonej oraz wieloaspektowej współpracy ONZ z UE w dziedzinie praw człowieka jest

${ }^{1}$ Zjawisko to stało się już przedmiotem badań politologicznych, choć wskazuje się na nadal niedostateczną liczbę gruntownych opracowań teoretycznych. Poświęcone było mu m.in. odbywające się w dniach 27-28 stycznia 2012 r. sympozjum pt. „Inter-Organizationalism in International Relations: Theories and Cases", zorganizowane wspólnie przez Vesalius College \& Institute for European Studies, Wolny Uniwersytet Brukselski (VUB) oraz Global Governance Institute (GGI).

${ }^{2}$ Można przytoczyć liczne przykłady takiej współpracy, m.in. współpracę Organizacji Międzynarodowego Lotnictwa Cywilnego ze Światową Organizacją Meteorologiczną w dziedzinie meteorologii lotniczej (zob. C. M. Shun et al., Meteorological Services to Aviation, „Bulletin Weather Climate Water" 58, 2009, nr 2 (April), s. 94-103, czy współpracę Unii Europejskiej z Radą Europy formalnie ustanowioną na podstawie Memorandum of Understanding z 2007 r. (tekst zob.: http:// www.coe.int/t/der/docs/MoU_EN.pdf). 
jak najbardziej wskazane. Mając wszakże na uwadze ograniczone ramy niniejszego opracowania, autorka skupi się na analizie ram prawnych tej kooperacji i jednocześnie podejmie próbę jej zwięzłej ewaluacji.

\section{PODSTAWA PRAWNA WSPÓŁPRACY UE Z ONZ}

Początkowo nie istniało generalne porozumienie o współpracy Wspólnot Europejskich z ONZ, a ich kooperacja była oparta na serii porozumień zawieranych przez każdą ze Wspólnot z poszczególnymi organizacjami wyspecjalizowanymi systemu Narodów Zjednoczonych. Pierwszym z nich było porozumienie zawarte w 1953 r. przez Europejską Wspólnotę Węgla i Stali z Międzynarodową Organizacją Pracy ${ }^{3}$. Po powstaniu Europejskiej Wspólnoty Gospodarczej doszło do podpisania kolejnych porozumień m.in. z MOP, FAO czy UNCTAD ${ }^{4}$. Jednakże dopiero w 1974 r. Zgromadzenie Ogólne ONZ przyznało EWG oficjalny status obserwatora, warto przy tym zaznaczyć, że był to pierwszy podmiot inny niż państwo, który uzyskał taka pozycję․

Relacje z ONZ zyskały nowy wymiar począwszy od lat dziewięćdziesiątych XX w., co miało związek z utworzeniem Unii Europejskiej oraz powstaniem zrębów Wspólnej Polityki Zagranicznej i Bezpieczeństwa, a formalnym wyrazem tego było utworzenie w 1994 r. Biura Łącznikowego Rady UE przy ONZ6 Począwszy od tego momentu, Unia Europejska zaczęła angażować się w liczne przedsięwzięcia związane z działalnością ONZ oraz zintensyfikowała pomoc finansowa dla Organizacji ${ }^{7}$.

Najnowszy etap we wzajemnych relacjach obu organizacji rozpoczą się wraz z wejściem w życie traktatu z Lizbony, kiedy to przy ONZ ustanowiono oficjalną Delegację Unii Europejskiej (European Union Delegation) działająca pod zwierzchnictwem Wysokiego Przedstawiciela do spraw Polityki Zagranicznej i Bezpieczeństwa. W tym miejscu warto wskazać, że ze strony ONZ kooperacja z UE jest realizowana przez Biuro ONZ w Brukseli (UN/UNDP Office in Brussels), którego zadaniem jest koordynacja działalności ponad 25 organizacji wyspecjalizowanych, agencji, funduszy i programów Narodów Zjednoczonych współpracujących z UE. Na czele Biura stoi dyrektor mianowany przez sekretarza generalnego ONZ, będący jego reprezentantem we wzajemnych stosunkach z Unia.

Relacje obu organizacji zyskały zupełnie nowy wymiar, gdy 3 maja 2011 r. Zgromadzenie Ogólne przyjęło, po długich staraniach Unii, rezolucję A/65/276 ${ }^{8}$,

${ }^{3}$ P. Brükner, The European Community and the United Nations, „The European Journal of International Law" 1, 1990, s. 175.

${ }^{4}$ M. O. Górska, The Development of the Legal Bases of EU-UN Cooperation, „Common Foreign and Security Forum" 5, 2007, nr 6, s. 8.

${ }^{5}$ Rezolucja Zgromadzenia Ogólnego nr 3208 z 11 października 1974 r., tekst zob.: http://www. un.org/ga/search/view_doc.asp?symbol=A/RES/3208(XXIX)\&Lang=E\&Area=RESOLUTION.

${ }^{6}$ Ang. EU Council Liaison Office.

7 M. O. Górska, op. cit., s. 9-10.

8 Tekst rezolucji dostępny na: http://www.un.org/ga/search/view_doc.asp?symbol=A/RES/65/ 276. 
która nadaje Unii Europejskiej wzmocniony status obserwatora przy Zgromadzeniu Ogólnym ONZ. Na mocy tej rezolucji UE może prezentować wspólne stanowisko przed organami ONZ, zyskała prawo prezentowania wystapień podczas sesji Zgromadzenia Ogólnego, może składać propozycje i wnioski o dokonywanie zmian, uzyskała prawo udzielania odpowiedzi, a także prawo dystrybucji dokumentów dla przedstawicieli UE. Warto jednak podkreślić, że co oczywiste, Unia Europejska nie uzyskała na mocy tej rezolucji prawa głosu w $\mathrm{ONZ}^{9}$. Choć przez niektórych badaczy nowy status prawny UE określany jest mianem statusu „superobserwatora” ${ }^{10}$, nie brak jednak też w literaturze głosów krytyki zarówno samej rezolucji, w której niewystarczająco wykorzystano możliwości, jakie dawałby traktat lizboński, jak i zakresu praw w niej przyznanych, które są określane jako niedostatecznie wzmacniające status Unii w $\mathrm{ONZ}^{11}$.

\section{OCHRONA PRAW CZLOWIEKA W DZIAŁALNOŚCI UE I ONZ - PODSTAWY PRAWNE ORAZ POTENCJALNE KOLIZJE REGULACJI}

Organizacja Narodów Zjednoczonych jest niewątpliwe pionierem rozwoju współczesnej idei ochrony praw człowieka i jakkolwiek warto spoglądać krytycznie na pewne jej poczynania w tej mierze, nie można nie doceniać ogromnego wkładu Organizacji w rozwój międzynarodowego prawa praw człowieka. Szczegółowe omawianie uregulowań prawnych w dziedzinie ochrony praw człowieka przyjętych w ramach działalności ONZ wykraczałoby poza ramy tego opracowania, należy jednak zaznaczyć, że normatywne podstawy uniwersalnego systemu ochrony praw człowieka zostały stworzone już w Karcie Narodów Zjednoczonych ${ }^{12}$, rozwinięte zaś w Powszechnej deklaracji praw człowieka i Paktach praw człowieka ${ }^{13}$ oraz licznych konwencjach specjalnych z dziedziny praw człowieka.

W przeciwieństwie do ONZ w początkowym okresie rozwoju Wspólnot Europejskich koncentrowano się na sferze integracji gospodarczej i nie kładziono szczególnego nacisku na materię ochrony praw człowieka ${ }^{14}$. Dzisiejszy standard ich ochrony w Unii Europejskiej osiagany był stopniowo, początko-

${ }^{9}$ Szerzej na ten temat zob. M. Zieliński, Unia Europejska jako obserwator przy Zgromadzeniu Ogólnym Organizacji Narodów Zjednoczonych, „Ruch Prawniczy, Ekonomiczny i Socjologiczny" 2013, z. 2, s. 50-53.

${ }^{10}$ Por. Ibidem, s. 44.

${ }^{11}$ Por. J. Wouters, J. Odermatt, T. Ramopoulos, The Status of The European Union at The United Nations after The General Assembly Resolution of 3 May 2011, Global Governance Opinions July 2011.

${ }_{12}$ Tekst zob.: Dz. U. 1947, Nr 23, poz. 90 ze zm. (dalej jako: KNZ).

${ }_{13}$ Tekst zob.: Międzynarodowy pakt praw politycznych i obywatelskich, Dz. U. 1977, Nr 38, poz. 167-zał; Międzynarodowy pakt praw gospodarczych, społecznych i kulturalnych, Dz. U. 1977, Nr 38, poz. 169-zał.

${ }^{14}$ T. Ahmed, I. de Jesús Butler, The European Union and Human Rights: An International Law Perspective, „The European Journal of International Law” 17, 2006, nr 4, s. 772-773. 
wo głównie za sprawą orzecznictwa Trybunału Sprawiedliwości, przez zapewnienie przestrzegania praw podstawowych, których celem było jednak przede wszystkim zapewnienie prawidłowej realizacji ówczesnego prawa wspólnotowego, dopiero z czasem ochrona praw człowieka zyskała wymiar normatywny ${ }^{15}$. Obecnie, jak wynika z postanowień Traktatów, idee ochrony i poszanowania tych praw należą do podstawowych wartości, na których zbudowana jest Unia Europejska.

$\mathrm{Na}$ marginesie niniejszych rozważań warto wskazać na kilka podstawowych problemów dotyczących wzajemnej relacji regulacji normatywnej praw człowieka w ONZ i UE. Jakkolwiek Unia Europejska wypracowała swój własny system ochrony praw człowieka, to nie odzwierciedla on szerokiego zakresu zobowiązań przyjętych przez państwa członkowskie UE na mocy traktatów wypracowanych pod egida ONZ. Warto podkreślić, że państwa członkowskie UE sa stronami wszystkich najważniejszych traktatów z dziedziny ochrony praw człowieka wypracowanych $\mathrm{w}$ systemie uniwersalnym, podczas gdy sama Unia Europejska jest jedynie stroną Konwencji o prawach osób niepełnosprawnych $^{16}$.

W rozważaniach kwestii wzajemnej relacji systemów prawnych obu organizacji i wynikających $\mathrm{z}$ nich zobowiązań państw członkowskich trzeba wskazać, że teoretycznie niewykluczona jest kolizja zobowiązań wynikających z prawa unijnego z art. $103 \mathrm{KNZ}$, który jak wiadomo przesądza, że „w razie sprzeczności między zobowiązaniami członków Organizacji Narodów Zjednoczonych, wynikajacymi z niniejszej Karty, a ich zobowiązaniami, wynikajacymi z jakiejkolwiek innej umowy międzynarodowej, zobowiązania wynikające z niniejszej Karty mają pierwszeństwo". Oczywiście jednak w praktyce trudno sobie wyobrazić, aby prawo unijne było w zasadniczy sposób sprzeczne ze zobowiązaniami wynikającymi z KNZ, zwłaszcza w kontekście treści art. 351 Traktatu o funkcjonowaniu Unii Europejskiej.

Wspomniany przepis stanowi, że jakkolwiek postanowienia Traktatów nie naruszają praw i obowiązków wynikających z umów zawartych przez państwa członkowskie UE przed 1 stycznia 1958 r., to jednak „w zakresie, w jakim umowy te nie sa zgodne z Traktatami, dane Państwo lub Państwa Członkowskie zastosują wszelkie właściwe środki w celu wyeliminowania stwierdzonych niezgodności". Oczywisty zatem staje się wniosek, że potencjalnie państwa członkowskie UE, będące jednocześnie członkami ONZ i stronami traktatów systemu ONZ, mogą stanąć przed istotnym dylematem, które zobowiązania przeważaja.

Jako przykład takiej kolizji można podać kazus Francji, która wypowiedziała Konwencję MOP nr 89 dotycząca pracy nocnej kobiet, stojąca, zdaniem tego państwa, w sprzeczności z unijnym podejściem do rozumienia pojęcia za-

15 J. Sozański, Prawa człowieka w Unii Europejskiej (po Traktacie Lizbońskim), WarszawaPoznań, 2010, s. 17; F. Jasiński, Karta Praw Podstawowych: struktura, zakres regulacyjny $i$ dotychczasowe znaczenie $w$ praktyce, w: J. Barcz (red.), Ochrona praw podstawowych $w$ Unii Europejskiej, Warszawa 2008, s. 38 i n.; J. Barcik, A. Wentkowska, Prawo Unii Europejskiej po Traktacie z Lizbony, Warszawa 2011, s. 280.

${ }_{16}$ Tekst konwencji zob.: Dz. U. 2012, poz. 1169 (dalej też jako: CRPD). Szersze rozważania na ten temat zawarte są w dalszej części niniejszego artykułu. 
kazu dyskryminacji i równouprawnienia ${ }^{17}$. Różnice aksjologiczne prawodawstwa UE i ONZ widoczne są także w odniesieniu do postanowień Konwencji w sprawie eliminacji wszelkich form dyskryminacji kobiet z 1979 r. (CEDAW). Podczas gdy przepisy CEDAW wyraźnie zakazuja dyskryminacji kobiet, wskazując jednocześnie na słabszą ich pozycję w stosunku do mężczyzn, co jest także ewidentne w dokumentach wypracowywanych przez Komitet CEDAW, UE zakazuje dyskryminacji ze względu na płeć (a więc nie tylko dyskryminacji kobiet, ale także mężczyzn) i nie uznaje $a$ priori, aby pozycja kobiet była gorsza od pozycji mężczyzn ${ }^{18}$.

Zasygnalizowane powyżej rozbieżności pozwalają sformułować następujące wnioski: po pierwsze - bez wątpienia różnice te mogą rodzić trudności w prawidłowym realizowaniu przez państwa zobowiązań wynikających z obu systemów, po drugie - jednostki podlegające jurysdykcji państw członkowskich UE mogą stanać w obliczu tzw. dwutorowego systemu (two-tier system) ochrony praw człowieka. W przypadkach gdy państwa członkowskie będą nadal uprawnione do działania indywidualnie w zakresie swojej kompetencji własnej, moga postępować zgodnie ze zobowiązaniami wynikającymi z Karty Narodów Zjednoczonych oraz traktatów ONZ-owskich dotyczacych praw człowieka. Jednak w tych obszarach, które wchodzą w zakres kompetencji UE, państwa członkowskie będa stosowały przepisy prawa UE, a te niekoniecznie odzwierciedlaja szersze standardy zawarte w instrumentach $\mathrm{ONZ}^{19}$. Zdaniem autorki jest to istotna kwestia wymagająca szerszego rozważenia, jednakże rozwijanie jej w niniejszym opracowaniu wykraczałoby poza jego zakres.

\section{SFERY WSPÓŁPRACY UE Z ONZ W DZIEDZINIE OCHRONY PRAW CZLOWIEKA}

Formy współpracy UE z ONZ w dziedzinie praw człowieka można podzielić na dwie kategorie: współpracę już realizowaną oraz potencjalną kooperację. Tak więc w pierwszej kategorii należy wskazać: finansowe wsparcie ONZ przez UE, inicjatywę „EU\&UN Partnership in Action” oraz program partnerstwa Unii Europejskiej z Funduszem Rozwoju Narodów Zjednoczonych (UNDP-EU Partnership). Ponadto rozważyć wypada aktywność Unii w ONZ-owskich ciałach traktatowych oraz Radzie Praw Człowieka. W postulowanej sferze współpracy mieści się zaś prawdopodobne przystapienie Unii do traktatów ONZ z dziedziny ochrony praw człowieka oraz potencjalne uczestnictwo UE w traktatowych procedurach kontrolnych.

${ }^{17}$ Idea przyświecająca Konwencji MOP została uznana za anachroniczną i paternalistyczna, zob.: The European Union and International Human Rights, Regional Office for Europe of the UN High Commissioner for Human Rights, s. 19, tekst zob.: http://www.europe.ohchr.org/Documents/ Publications/EU_and_International_Law.pdf.

18 Zob. N. Buchowska, Relacja między realizacja praw kobiet a stereotypami płci $w$ świetle standardów ONZ i Unii Europejskiej, „Nauka” 2013, 2, s. 73-93.

19 Por. także: The European Union..., s. 8. 
Unia Europejska oraz jej państwa członkowskie, jak wskazuje ONZ, udzielają wspólnie największego wsparcia finansowego dla systemu ONZ. Jakkolwiek UE, nie będąc członkiem ONZ, nie dokonuje wpłat do jej regularnego budżetu, warto wskazać, że państwa członkowskie Unii pokrywaja łącznie blisko 35\% regularnego budżetu Organizacji (czyli 2,5 mld USD w latach $2012-2013)^{20}$ i ponad $36 \%$ budżetu operacji pokojowych (ok. 2,6 mld USD w okresie od czerwca 2012 do czerwca 2013) ${ }^{21}$. Sama Unia Europejska wpłaciła w 2011 r. blisko 360 mln USD na pokrycie działalności Programu Rozwoju Narodów Zjednoczonych ${ }^{22}$. W 2005 r. Komisja Europejska przekazała 1,35 mld USD celem wsparcia ONZ-owskich programów i projektów pomocy zewnętrznej ${ }^{23}$. W maju 2013 r. Komisja Europejska udzieliła dodatkowego wsparcia w wysokości 10 mln euro Wysokiemu Komisarzowi ds. Praw Człowieka ONZ, które pokryło ponad trzy czwarte luki budżetowej Biura Wysokiego Komisarza $^{24}$. Bez zbędnej przesady można zatem stwierdzić, że doniosłe wsparcie finansowe, jakiego udzielają Unia Europejska oraz jej państwa członkowskie, ma ogromne znaczenie dla prawidłowego realizowania przez ONZ - borykającej się przecież z permanentnymi problemami finansowymi - jej zadań statutowych, w tym oczywiście działalności na rzecz ochrony praw człowieka. Niewątpliwie taki poziom dotacji do budżetu Organizacji może rodzić pokusę ze strony UE wykorzystywania tego faktu jako swoistej karty przetargowej. To z kolei bez wątpienia spotykać będzie się z silną opozycją administracji Narodów Zjednoczonych oraz państw opłacających niższe składki, które z pewnością będą podkreślać, że ONZ oparta jest na zasadzie suwerennej równości wszystkich członków (niezależnej od wysokości opłacanej składki) ${ }^{25}$.

Jak już wspomniano, Unia Europejska od momentu swojego powstania angażowała się w liczne przedsięwzięcia związane z działalnością ONZ. Obecnie kooperacja realizowana jest w dwóch najważniejszych nurtach: ogólnej współpracy Unii Europejskiej z Organizacją Narodów Zjednoczonych w ramach inicjatywy o nazwie European Union \& United Nations Partnership in Action oraz pod postacia współpracy Unii Europejskiej z Funduszem Rozwoju Narodów Zjednoczonych (UNDP-EU Partnership).

\footnotetext{
${ }^{20}$ Cały dwuletni budżet wynosi ok. 5 mld USD, por. Regular Budget 2012-2013, http://www. un.org/en/hq/dm/pdfs/oppba/Regular\%20Budget.pdf.

${ }^{21}$ Budżet misji pokojowych w okresie od czerwca 2012 r. do czerwca 2013 r. wynosi ok. 7,33 mld USA, por. rezolucja Zgromadzenia Ogólnego nr A/C.5/66/18, tekst zob.: http://www.un.org/ga/ search/view_doc.asp?symbol=A/C.5/66/18.

${ }^{22}$ Dane za: EU ranks third top donor to UNDP in 2011, http://www.eu-un.europa.eu/articles/ en/article_13114_en.htm.

${ }^{23}$ Dane za: About the EU at the UN, European Union \& United Nations Partnership in Action, http://www.eu-un.europa.eu/articles/en/article_9389_en.htm.

${ }^{24}$ EU Commission to provide an exceptional $€ 10$ million contribution for Office of the UN High Commissioner for Human Rights, artykuł dostępny na stronie, European Union \& United Nations Partnership in Action, http://www.eu-un.europa.eu/articles/fr/article_13482_fr.htm.

${ }^{25} \mathrm{Na}$ marginesie można wskazać, że w przypadku ONZ mamy do czynienia z niebywała dysproporcją wkładów finansowych, wpłaty 29 państw (państwa członkowskie UE oraz USA) tworzą bowiem łącznie 57\% budżetu ONZ.
} 
Program Partnership in Action, który corocznie wspierany jest przez UE suma ok. 1,5 mld euro ${ }^{26}$, obejmuje swoim szerokim zakresem takie dziedziny, jak: rozbrojenie i nieproliferacja broni jądrowej, rozwój, handel, sprawy gospodarcze i społeczne, migracja, azyl i zdrowie, jednakże można stwierdzić, że kluczową sferą współpracy są sprawy ochrony praw człowieka oraz pomoc humanitarna. Efekty tego współdziałania sa publikowane w okresowych raportach opracowywanych przez Stałe Przedstawicielstwo ONZ przy UE w Brukseli. Opublikowano już 8 takich raportów: pierwszy z nich został wydany w roku 2007 i obejmował swoją treścia aktywność, począwszy od 2005, ostatni zaś (pt. Saving and Improving Lives: UN-EU Partnership for Food and Nutrition Security 2008-2012), został opublikowany w październiku $2013^{27}$.

Kooperacja obu organizacji w dziedzinie praw człowieka realizowana w ramach omawianej inicjatywy obejmuje działania majace na celu m.in.: wspieranie praworządności, budowę i wzmacnianie lokalnych, demokratycznych struktur władzy, wspieranie krajowych systemów sądowniczych, a także wpływanie na zwiększenie stopnia przestrzegania praw człowieka i norm międzynarodowych, przez uwzględnianiu tzw. perspektywy płci w zarządzaniu, promowanie praw dzieci, promowanie godnej pracy i norm pracy oraz wspieranie międzynarodowej ochrony uchodźców. Tytułem przykładu można podać następujące działania szczegółowe: udzielenie wsparcia i dostarczenie sprzętu lokalnym organizacjom pozarządowym i ośrodkom kryzysowym świadczącym pomoc kobietom - ofiarom przemocy w Mauretanii i Tunezji, zapewnienie bezpłatnej pomocy prawnej dla ofiar przemocy seksualnej w Demokratycznej Republice Konga, działania na rzecz ograniczenia rytualnego obrzezania kobiet oraz małżeństw nieletnich w Egipcie, Erytrei, Etiopii, Indiach i Sudanie, wsparcie ochrony praw dzieci w konfliktach zbrojnych w Kolumbii, Myanmarze i Nepalu, finansowanie pomocy prawnej dla uchodźców palestyńskich w Libanie ${ }^{28}$.

Z kolei współpraca z Funduszem Rozwoju Narodów Zjednoczonych obejmuje takie sfery, jak: działanie na rzecz zmniejszenia ubóstwa, zapobieganie kon-

\footnotetext{
${ }^{26}$ Szczegółowe dane dostępne na stronach poszczególnych raportów. Strona główna, na której dostępna jest lista raportów: http://www.undp.org/content/brussels/en/home/library/partnershipreports.html.

${ }^{27}$ Raporty w porządku chronologicznym: 1. The Partnership between the UN and the EU. The United Nations and the European Commission Working Together in Development and Humanitarian Cooperation (wyd. 2007), 2. Improving Lives: Results from the Partnership of the United Nations and the European Commission in 2006 (wyd. 2007), 3. Improving Lives: Results from the Partnership of the United Nations and the European Commission in 2007 (wyd. 2008), 4. Renewing Hope, Rebuilding Lives: Partnership between the United Nations and the European Union in Post-Crisis Recovery 2009 Report (wyd. 2009), 5. Improving Lives: Results of the Partnership between the United Nations and the European Union in 2009 (wyd. 2010), 6. Improving Lives: Partnership between the United Nations and the European Union in 2010, 7. Saving and Improving Lives: Partnership between the United Nations and the European Union in 2011, 8. Saving and Improving Lives: UN-EU Partnership for Food and Nutrition Security 2008-2012; treść wszystkich raportów zob.: http://www.undp.org/content/brussels/en/home/ library/partnership-reports.html.

${ }^{28}$ Zob. Saving and Improving Lives: Partnership between the United Nations and the European Union in 2011, passim.
} 
fliktom i kryzysom, odbudowa społeczeństw, energia, środowisko, naturalne; w dziedzinie praw człowieka zaś koncentruje się przede wszystkich na szeroko pojętym wspieraniu budowy demokratycznych rządów. Do kluczowych działań podejmowanych w ramach programu UNDP-EU Partnership należy wspieranie organizowania przejrzystych i sprawiedliwych wyborów oraz budowy demokratycznych parlamentów. Ponadto zamierzeniem programu jest promocja podnoszenia poziomu przestrzegania praw człowieka i kultury prawnej oraz zwiększanie partycypacji społecznej lokalnej ludności, jak również wpływanie na realizację zasady równouprawnienia kobiet i mężczyzn oraz zwiększanie udziału kobiet w życiu publicznym ${ }^{29}$.

Istotna kwestia jest ocena skuteczności i efektywności obu opisanych wyżej projektów współpracy. W 2008 r. niezależna firma konsultingowa na zlecenie UE i ONZ dokonała ewaluacji programu ich partnerstwa ${ }^{30}$. W obszernym raporcie dokonano generalnej pozytywnej recenzji wspólnych inicjatyw oraz sformułowano konkluzję, że obie organizacje czerpią korzyści z tej formy współpracy. Wskazano, że charakterystyczną cechą tej kooperacji jest próba efektywnego wykorzystania potencjału potężnej organizacji globalnej, borykającej się jednak z ciagłymi trudnościami finansowymi, z potencjałem organizacji regionalnej, która, co oczywiste, nie ma struktur instytucjonalnych rozsianych po całym świecie, dysponuje jednak znacznie większymi środkami pieniężnymi ${ }^{31}$, a każda z organizacji działająca samodzielnie nie byłaby w stanie zrealizować tak wielu przedsięwzięć. Ponadto pozytywnie oceniono sprawna, co do zasady, współpracę oraz dobra wolę obu organizacji, przyjmującą m.in. postać: „zwiększenia harmonizacji działań donatorów w zakresie udzielania pomocy i zracjonalizowania niektórych procedur"32. Wśród zjawisk negatywnych wymieniano przede wszystkim problemy na poziomie operacyjno-administracyjnym, w postaci trudności dotyczących zarządzania działaniami interwencyjnymi ${ }^{33}$. Dla przykładu z jednej strony Komisja Europejska skarżyła się na duże opóźnienia sprawozdawcze personelu ONZ dotyczące rozliczania środków, co skutkowało potencjalną odpowiedzialnością pracowników Komisji, którzy ponoszą osobistą odpowiedzialność majątkową za środki, które im powierzono. Z drugiej zaś strony ONZ podnosiła, że UE jest niezwykle wymagającym darczyńca, ponieważ oczekuje od ONZ licznych raportów i ewaluacji oraz ścisłego przestrzegania terminów, co wymaga od Organizacji odrębnego zarządzania funduszami

${ }^{29}$ Democratic Governance, Democratic Governance Group Bureau for Development Policy United Nations Development Programme, New York, October 2011, tekst dostępny na: http:// www.undp.org/content/dam/undp/library/corporate/fast-facts/english/FF-Democratic-Governance-011.pdf.

${ }^{30}$ Zob. raport firmy Aide à la Décision Economique, pt. Evaluation of Commission's External Cooperation with Partner Countries through the Organisations of the UN Family, Bruksela 2008.

${ }_{31}$ Budżet regularny ONZ na lata 2014-2015 wynosi 5,4 mld USD (http://www.un.org/News/ Press/docs/2013/gaab4080.doc.htm), budżet zaś Unii Europejskiej na rok 2013 wynosił 150 mld euro (zob.: http://ec.europa.eu/budget/library/biblio/publications/2013/budget_folder/print/KV3012856PLC.pdf).

\footnotetext{
${ }^{32}$ Ibidem, s. 66.

${ }^{33}$ Ibidem.
} 
Unii. Ponadto wskazywano na trudności wynikające głównie z niewypełniania przez obie organizacje sprzecznych oczekiwań i wymogów. Unia Europejska bowiem chciałaby nie być postrzegana wyłącznie jako donator i oczekiwałaby, że partnerstwo oznacza wspólne zaangażowanie w podejmowanie kluczowych decyzji. Z kolei ONZ postrzega partnerstwo jako formę okazywania wzajemnego szacunku pomiędzy równymi partnerami i próby ingerencji ze strony Unii uważa za niewłaściwe ${ }^{34}$.

Kolejna z form współpracy UE z ONZ jest zaangażowanie Unii w działalność Rady Praw Człowieka, powołanej w 2006 r. Komisji Praw Człowieka ${ }^{35}$. W początkowej fazie dyskusji nad przebudową ogólnego systemu monitoringu praw człowieka, pomimo swojego generalnego wsparcia idei reformatorskich, UE prezentowała dość konserwatywne podejście, nie wzywając do radykalnej zmiany opartych na Karcie NZ mechanizmów i dopiero po publikacji raportu Kofiego Annana, w którym zaproponował on utworzenie Rady Praw Człowieka, Unia wyraziła swoje zdecydowane poparcie dla tej koncepcji ${ }^{36}$.

Chociaż status UE przy ONZ został znacząco wzmocniony wspominanąjuż rezolucją A/65/276 z 2011 r., to obecnie współpraca Unii z Radą Praw Człowieka może odbywać się wyłącznie na poziomie nieformalnym. Status obserwatora pozwala wprawdzie Unii na udział w debatach, inicjowanie lub wspieranie przyjmowania rezolucji oraz wygłaszanie oświadczeń na forum $\operatorname{Rady}^{37}$, ale jako podmiot niebędący członkiem ONZ, Unia nie może samodzielnie zasiadać, a co za tym idzie, głosować, w organach ONZ, w tym - w Radzie Praw Człowieka. Do składu Rady moga zostać wybrane jedynie państwa członkowskie Unii, które zabierając głos na forum Rady, mogą prezentować stanowisko w imieniu Unii Europejskiej ${ }^{38}$.

Próba zwięzłej oceny dotychczasowej aktywności Unii w Radzie pozwala stwierdzić, że jest ona uznawana za nie w pełni skuteczną. Podkreśla się, że w związku z początkową odmową USA uczestnictwa w Radzie niektórzy pokładali duże nadzieje w Unii Europejskiej, oczekując, że weźmie ona na siebie ciężar przewodnictwa w sprawach praw człowieka. Niestety okazało się, że Unia nie była zdolna odegrać kluczowej roli w tej mierze, a jej działania były określane jako zbyt defensywne ${ }^{39}$. Jak się wydaje, jedną z przyczyn takiego stanu rzeczy jest fakt, że Unia często nie może osiagnąć wewnętrznego kon-

${ }^{34}$ Evaluation of Commission's External Cooperation with Partner Countries through the Organisations of the UN family, s. 48.

${ }^{35}$ Szerzej na ten temat zobacz: K. E. Smith, Speaking with One Voice but Having Little Impact: The EU at the UN's Human Rights Council, Garnet Conference, Brussels, April 2008 (tekst dostępny na: http://www.ies.be/files/repo/conference2008/EUinIA_III_1_Smith.pdf) oraz eadem, The European Union and the Review of the Human Rights Council, Brussels 2011.

${ }^{36}$ K. E. Smith, Speaking with One Voice..., s. 3-4.

${ }^{37}$ Oświadczenia UE na forum RPC zob.: http://eeas.europa.eu/delegations/un_geneva/eu_ statments/human_right/index_en.htm.

${ }^{38}$ Szerzej na ten temat: J. Wouters, K. Meuwissen, The European Union at the UN Human Rights Council. Multilateral Human Rights Protection Coming of Age?, Leuven Centre for Global Governance Studies, Working Paper no. 126, December 2013, s. 6.

${ }^{39}$ K. E. Smith, Speaking with One Voice..., s. 8 i n., J. Wouters, K. Meuwissen, op. cit., s. 7. 
sensusu, a wypracowanie wspólnego stanowiska napotyka trudności natury praktycznej, przez co UE nie prezentuje jednolitego stanowiska ${ }^{40}$.

Z kolei wśród sfer potencjalnej współpracy Unii z Radą Praw Człowieka wymienia się udział tej pierwszej w procedurach specjalnych (special procedures) oraz w procesie Powszechnego Okresowego Przeglądu Praw Człowieka (Universal Periodic Reports). W odniesieniu do procedur specjalnych, możliwe byłoby zaangażowanie Unii przez ekspertów w procedurę mandatów tematycznych, w odniesieniu do skarg indywidualnych, jak również prowadzenie badań na terytorium UE jako całości, na tej samej zasadzie jak w przypadku „wizyt krajowych” („country visits”), co pozwoliłoby na szerszą analizę stosownych polityk UE. Ponadto wskazuje się, że Unia, jako obserwator przy Zgromadzeniu Ogólnym, mogłaby dobrowolnie brać udział w procedurze Powszechnego Okresowego Przeglądu ${ }^{41}$.

Wreszcie rozważenia wymaga kwestia zaangażowania UE w traktatowe mechanizmy monitorujące prawa człowieka. Jak wiadomo, Unia Europejska z jednym wyjątkiem - nie jest stroną konwencji specjalnych ONZ z dziedziny ochrony praw człowieka. Wyjątek ten, którym jest Konwencja o prawach osób niepełnosprawnych (CRPD - Unia zatwierdziła ją 23 grudnia $2010 \mathrm{r}^{42}$ ), wydaje się jednak znaczacy. Na mocy art. 35 CRPD Unia Europejska jest bowiem zobowiązana, do przedstawiania Komitetowi ds. Praw Osób Niepełnosprawnych raportów zawierających „szczegółowe sprawozdanie dotyczące środków podjętych w celu realizacji zobowiązań wynikających z niniejszej konwencji oraz na temat postępu dokonanego w tym zakresie" ${ }^{43}$. Warto podkreślić, że zgodnie z art. 44 ust. 2 CRPD, jej postanowienia stosowane sa wobec Unii „w zakresie jej kompetencji”. Ze względu na ten fakt CRPD nałożyła, moca art. 44 ust. 1, na organizacje integracji regionalnej obowiązek zadeklarowania, w dokumencie zatwierdzenia, zakresu kompetencji w sprawach regulowanych przez Konwencję, a także obowiązek informowania depozytariusza o wszelkich istotnych zmianach zakresu tychże kompetencji. Unia uczyniła zadość temu obowiązkowi w swojej deklaracji, w której wyjaśniła kwestię kompetencji wyłącznych, dzielonych oraz uzupełniających, dołączając szczegółową listę aktów prawnych, które dotyczą spraw regulowanych przez CRPD, informujac jednocześnie, że będzie powiadamiać depozytariusza o ewentualnej zmianie zakresu swoich kompetencji ${ }^{44}$.

Niestety ocena realizacji innych obowiązków Unii wynikajacych z Konwencji nie może być pozytywna. Zgodnie z postanowieniami art. 35 ust. 1 CRPD UE powinna złożyć swój pierwszy raport po upływie dwóch lat od wejścia w życie traktatu w stosunku do niej, czyli do 23 stycznia 2013 r. ${ }^{45}$ Mimo to zgodnie

${ }^{40}$ Por. J. Wouters, K. Meuwissen, op. cit., s. 6.

41 Zob. The European Union and International Human Rights..., s. 41.

${ }^{42}$ United Nations, Treaty Series, vol. 2515, s. 3. Dane dotyczace ratyfikacji zob.: https://treaties. un.org/pages/ViewDetails.aspx?src=TREATY\&mtdsg_no=IV-15\&chapter=4\&lang=en\#EndDec

${ }^{43}$ Art. 35 Konwencji.

${ }_{44}$ Treść deklaracji zob.: https://treaties.un.org/pages/ViewDetails.aspx?src=TREATY\&mtdsg_ no=IV-15\&chapter=4\&lang=en\#EndDec (dalej jako: CRPD lub Konwencja).

${ }^{45}$ UE zatwierdziła Konwencję 23 grudnia 2010 r., weszła ona w stosunku do niej w życie po upływie 30 dni, czyli 23 stycznia 2011 r. - i od tego dnia należy liczyć dwuletni okres na złożenie raportu. 
z informacjami przedstawionymi zarówno w Raporcie z dziewiątej sesji Komitetu ds. Osób Niepełnosprawnych z 1 października 2013 r., jak i z innymi dostępnymi danymi, Unia Europejska nie złożyła do tej pory swojego raportu, dołączając do niechlubnej grupy 52 stron Konwencji, które pozostają w zwłoce $\mathrm{w}$ realizacji swojego obowiązku sprawozdawczego ${ }^{46}$. Jakkolwiek przypuszczać można, że zwłoka ta spowodowana jest problemami natury biurokratycznej, nie zaś niechęcią do wywiązywania się ze zobowiązań międzynarodowych w dobrej wierze, stan ten rzuca złe światło na Unię Europejska, która chce przecież być postrzegana jako liderka procesu rzeczywistej realizacji praw człowieka.

W tym kontekście należy stwierdzić, że głębokiego rozważenia wymaga kwestia wydolności struktur instytucjonalnych Unii Europejskiej oraz kwestia niezbędnej reformy tychże, tak aby zapewnić właściwą współpracę UE z Komitetem. Postulat ten nabiera szczególnego znaczenia wobec faktu, że ze strony ekspertów ONZ płyną postulaty rozszerzenia udziału Unii w systemie ONZ-owskiej traktatowej ochrony praw człowieka ${ }^{47}$. Podobne dezyderaty, co należy uznać za znamienne, formułowane są także ze strony organów konsultacyjnych samej Unii, które sugeruja Komisji Europejskiej zarówno wzmocnienie już istniejaccych form współpracy, jak i rozszerzenie jej m.in. poprzez rozważenie możliwości „ratyfikacji innych traktatów dotyczących praw człowieka, takich jak Konwencja o prawach dziecka i Konwencja w sprawie likwidacji wszelkich form dyskryminacji kobiet, oraz ich protokołów fakultatywnych ${ }^{48}$ " oraz poprzez udział UE „w prowadzonych obecnie rozmowach w nieformalnych grupach roboczych ONZ, w których rozważa się opracowanie projektu nowego tematycznego traktatu ONZ o prawach człowieka dotyczacego osób starszych [...]"49.

Niewątpliwe analizowane powyżej postanowienia Konwencji o prawach osób niepełnosprawnych, jak i zastosowana procedura mogłyby posłużyć za wzorzec postępowania w przypadku ewentualnych zmian w innych, kluczowych ONZ-owskich traktatach z dziedziny praw człowieka w celu umożliwienia Unii Europejskiej przystapienia także do nich. Tym samym przyjęcie CRPD przez UE potencjalnie może wpłynąć na zmianę dotychczasowego stanowiska i rozważenie możliwości przystapienia tej organizacji do pozostałych konwencji ONZ-owskich. Niestety zastanowić się trzeba, czy formułowanie takich oczekiwań nie jest zbyt optymistyczne, wobec faktu, że Unia obecnie nie wypełnia należycie swoich obowiązków wynikających z jednej/jedynej kon-

${ }^{46}$ Dane wg stanu na 5 lutego 2014 r., por. por. m.in.: Report of the Committee on the Rights of Persons with Disabilities on its ninth session, 15-19 April 2013, dokument nr CRPD/C/9/2, s. 17, tekst dostępny na: http://tbinternet.ohchr.org/_layouts/treatybodyexternal/TBSearch.aspx?Lan $\mathrm{g}=$ en\&TreatyID=4\&DocTypeID=27 oraz dane Disability Council International (DisabCouncil), dostępne: http://disabilitycouncilinternational.org/Resources.php.

${ }^{47}$ Zob. The European Union and International Human Rights..., s. 51.

48 Opinia Europejskiego Komitetu Ekonomiczno-Społecznego $w$ sprawie roli EKES-u we wdrażaniu i monitorowaniu przez instytucje UE Konwencji Narodów Zjednoczonych o prawach osób niepetnosprawnych (opinia z inicjatywy własnej), Bruksela, 12 grudnia 2012 r., s. 6, tekst dostępny: http://www.eesc.europa.eu/?i=portal.en.soc-opinions.23133.

49 Ibidem. 
wencji, której jest stroną. Można zatem mieć uzasadnione wątpliwości, czy bez odpowiednich zmian funkcjonowania instytucji i organów UE oraz opracowania i wdrożenia stosownych procedur składania raportów dla ONZ-owskich ciał traktatowych, postulaty zwiększenia zaangażowania UE w omawianej sferze nie pozostaną całkowicie nierealnymi i nierealizowalnymi życzeniami.

Tym bardziej krytycznie należy odnieść się do innych sugestii, dotyczących określenia nowego wymiaru relacji ONZ z UE, który miałby polegać na sporządzaniu zamiast 28 raportów okresowych państw członkowskich UE jednego sprawozdania, które rozważane byłoby przez każdy z komitetów, co miałoby wpłynąć na zmniejszenie obciążeń administracyjnych i umożliwiłoby komplementarność procesu monitorowani ${ }^{50}$. Realizacja tego postulatu byłaby jednak szczególnie trudna, jako że należałoby dokonać dogłębnego rozważenia zakresu kompetencji Unii i państw członkowskich, tak aby każdy z podmiotów składał raport w zakresie własnych kompetencji. Mając na uwadze dotychczasowe trudności, w obecnym stanie rzeczy należy zatem tę sugestię uznać za prawdopodobnie niewykonalna.

\section{PODSUMOWANIE}

Utrzymywane od kilkudziesięciu lat stosunki pomiędzy Wspólnotami Europejskimi a ONZ zostały zintensyfikowane wraz z powstaniem Unii Europejskiej, a przyjęcie przez Zgromadzenie Ogólne Narodów Zjednoczonych w 2011 r. rezolucji A/65/276, dającej UE możliwość jeszcze pełniejszego udziału w pracach Organizacji, ma szansę wpłynąć na dalszy rozwój i pogłębienie tych relacji.

Włączenie problematyki praw człowieka do systemu prawnego Unii, początkowo nieznajdujacej się w sferze integracji w ramach Wspólnot, przyniosło dwojakiego rodzaju konsekwencje. Z jednej strony sa to, wspomniane w niniejszym artykule, potencjalne kolizje zobowiązań państw wynikających z obu systemów prawnych oraz powstanie tzw. dwutorowego systemu ochrony praw jednostek. Z drugiej - to rozszerzenie obszaru zainteresowań UE stworzyło możliwość rozwoju nowej płaszczyzny współdziałania UE z ONZ. Wymiar praktyczny współpracy obu organizacji w dziedzinie praw człowieka tworza zwłaszcza inicjatywy EU\&UN Partnership in Action oraz EU-UNDP Partnership, które pozwalają na połączenie wysiłków Unii i Narodów Zjednoczonych przez wykorzystanie środków finansowych tej pierwszej oraz globalnych struktur i doświadczenia tej drugiej, tym samym znaczace wsparcie finansowe, jakiego UE udziela ONZ, bez wątpienia pozwala Narodom Zjednoczonym na pełniejsze osiaganie celów statutowych.

Jakkolwiek inicjatywy partnerskie zasługują na ogólną pozytywną ocenę, to ich realizacja nie odbywa się bez przeszkód, obejmujących przede wszystkim bieżące problemy administracyjne, a w szerszym kontekście - wynikajacych z różnic w rozumieniu idei partnerstwa. Należy uznać, że Unia słusznie oczekuje, zgodnie ze swoimi standardami, skrupulatnej sprawozdawczości

${ }^{50}$ The European Union and International Human Rights..., s. 37. 
finansowej oraz możliwości współdecydowania o sposobach wykorzystywania przekazywanych środków. ONZ zaś spodziewa się, że zostanie jej pozostawiona większa swoboda działania, co może rodzić ze strony UE uzasadnione obawy nie w pełni właściwego i rzetelnego wykorzystania dotacji. Wydaje się zatem konieczne położenie nacisku na wspólne wypracowanie spójnego i efektywnego systemu zarządzania dotacjami UE dla ONZ.

Podsumowując zaangażowanie UE w działalność ONZ-owskich organów monitorujących przestrzeganie praw człowieka, należy stwierdzić, że wzmocnienie udziału Unii w tych procedurach byłoby korzystne dla samej UE, a zwłaszcza dla jednostek znajdujacych się w sferze oddziaływani jej legislacji. Ważne jest jednak, aby Unia uczestniczyła w tych procedurach w sposób wyraźny, efektywny i rzetelny. Wskazane byłoby zatem wyraźniejsze akcentowanie jednolitego stanowiska w Radzie Praw Człowieka. Absolutnie konieczne zaś jest sumienne i terminowe wykonywanie przez UE obowiązków ciązacych na niej na mocy Konwencji o prawach osób niepełnosprawnych. Niewłaściwa realizacja tych zobowiązań stawia pod dużym znakiem zapytania szersze włączenie się Unii do traktatowego systemu kontroli realizacji praw człowieka, które nastapiłoby po przystapieniu przez nią do pozostałych ONZ-owskich konwencji.

Obie organizacje muszą być zdolne do przezwyciężenia bieżących problemów oraz skłonne do wykazania dostatecznej determinacji w usprawnianiu i modyfikowaniu swojej współpracy, tak aby przyświecające ich partnerstwu hasło „saving and improving lives” nie pozostało wyłącznie atrakcyjnie brzmiącym, ale pustym sloganem.

dr Natalia Buchowska

Uniwersytet im. Adama Mickiewicza w Poznaniu

nabu@amu.edu.pl

\author{
THE LEGAL FRAMEWORK OF COLLABORATION BETWEEN \\ THE EUROPEAN UNION AND THE UNITED NATIONS \\ IN THE AREA OF HUMAN RIGHTS PROTECTION
}

\title{
Sum mary
}

\begin{abstract}
The current abundance of governmental international organisations, combined with a wide spectrum of tasks put before them frequently leads to a situation in which statutory tasks of those organisations clash or overlap. This doubling of tasks of individual organisations has resulted in development of a new area of organisational activity termed inter-organisationalism, based on collaboration of international organisations of similar interests and goals. One of the prominent spheres in which such collaboration flourishes is human rights protection, where collaboration between the United Nations and the European Union is particularly noteworthy as being an attempt to combine and use efficiently the potential of a huge but not free from financial difficulties global organisation with the opportunities available to a regional organisation which, although lacking global institutional structures, enjoys access to substantially much larger financial resources. The purpose of this article is to present a concise analysis of the existing and potential legal forms of collaboration of these two organisations (the UN and the EU) in the area of human rights protection, and to identify the effects of such collaboration as well as potential areas of conflict between their legal systems.
\end{abstract}


Copyright of Journal of Law, Economics and Sociology is the property of Faculty of Law and Administration of Adam Mickiewicz University in Poznan and its content may not be copied or emailed to multiple sites or posted to a listserv without the copyright holder's express written permission. However, users may print, download, or email articles for individual use.

Właścicielem praw autorskich do „Ruchu Prawniczego, Ekonomicznego i Socjologicznego” jest Wydział Prawa i Administracji Uniwersytetu im. Adama Mickiewicza w Poznaniu. Zawartość czasopisma nie może być kopiowana, przesyłana do innych stron internetowych bądź zamieszczana na blogach bez pisemnej zgody wydawcy. Niemniej artykuły można drukować, kopiować lub przesyłać w formie elektronicznej na własny użytek. 